\title{
Analisis Serapan Kredit Investasi UMKM di Aceh
}

\author{
Hamdani $^{1 *}$, Josi Farmiati ${ }^{2}$ \\ ${ }^{1 *}$ Program Studi Manajemen Keuangan Sektor Publik, Politeknik Kutaraja, Kota \\ Banda Aceh, Provinsi Aceh, Indonesia. \\ 2 Program Studi Administrasi Perkantoran, Politeknik Kutaraja, Kota Banda Aceh, \\ Provinsi Aceh, Indonesia.
}

\begin{abstract}
Abstrak. Penelitian ini bertujuan untuk melibat bubungan antara variable kredit investasi dan kinerja keuangan UMKM dalam penyerapan kredit investasi di Aceh. Penelitian ini menggunakan data time series 2019-2020 dengan menetapkan sebanyak 24 observer yang dipilih. Metode analisis yang digunakan dalam penelitian ini adalah uji kausalitas dengan bantuan software Eviews 7. Penelitian dilakukan di Provinsi Aceh pada periode April-juli 2020. Hasil penelitian menunjukkan bahwa terdapat bubungan kausalitas satu arah antara variabel Kredit Investasi (LKI) dengan variabel Kinerja Kenangan (LKK) UMKM dengan probablitas 0,065 dan taraf signifikansi 10 persen. Artinya kredit investasi yang dikucurkan oleh bank kepada UMKM dapat mempengarubi kinerja keuangan UMKM dan bubungan tersebut positif dan signifikan pada taraf 10 persen. Hasil penelitian menunjukkan bahwa penyaluran kredit investasi oleb bank terbadap UMKM di Aceh dapat berdampak positif bagi pertumbuhan keuangan usaha UMKM.
\end{abstract}

Kata kunci: Kredit Investasi; UMKM; Bank Indonesia; Kredit Usaha Rakyat.

Abstract. This study aims to see the relationship between investment credit variables and the financial performance of MSMEs in the absorption of investment credit in Aceh. This study uses the 2019-2020 time series data by determining as many as 24 selected observers. The analytical method used in this study is a causality test with the help of Eviews 7 software. The study was conducted in Aceh Province in the period April-July 2020. The results showed that there was a one-way causality relationship between the Investment Credit (LKI) variable and the Financial Performance (LKK) variable. SMEs with a probability of 0.065 and a significance level of 10 percent. This means that investment loans that are channeled by banks to MSMEs can affect the financial performance of MSMEs and have a positive and significant relationship at the level of 10 percent. The results of the study indicate that the distribution of investment credit by banks to MSMEs in Aceh can have a positive impact on the financial growth of MSME businesses.

Keywords: Investment Credit; MSME; Bank Indonesia; People's Business Credit. 


\section{Pendahuluan}

Kondisi pandemi Covid-19 yang melanda Indonesia dan dunia sejak Maret 2020 lalu telah berdampak sangat serius terhadap perekonomian nasional. Dalam beberapa bulan terakhir laju pertumbuhan ekonomi Indonesia mengalami penurunan yang cukup signifikan dan gagal mencapai target yang direncanakan dalam APBN (Anggaran Pendapatan dan Belanja Negara) tahun 2020. Situasi sulit tersebut telah mendorong pemerintah untuk melakukan berbagai perubahan kebijakan terkait perekonomian dan usaha mikro kecil dan menengah (UMKM). Salah satu kebijakan itu yaitu melalui Kementerian Keuangan dan Kementerian Koperasi dan UKM Republik Indonesia, pemerintah meluncurkan bantuan tunai (cash grant) bagi UMKM secara nasional sebesar Rp. 2.400.000,. Pemberian bantuan tersebut dimaksudkan sebagai jaring pengaman ekonomi bagi UMKM agar tetap eksis untuk dapat terus berproduksi dan memberikan kontribusi positif bagi ekonomi nasional hingga pemulihan ekonomi tercipta.

UMKM merupakan salah satu pelaku ekonomi terbesar di Indonesia. Kelompok UMKM memiliki peran sangat strategis dalam pembangunan perekonomian nasional dan daerah terutama sebagai penyumbang bagi pendapatan negara dan memajukan ekonomi kerakyatan. Sebagai pelaku usaha paling banyak jumlahnya dan tersebar di berbagai daerah, UMKM dapat berfungsi sebagai penggerak ekonomi lokal dan menciptakan kemakmuran bagi ekonomi masyarakat setempat. UMKM juga sering disebut sebagai mesin pertumbuhan ekonomi kelas menengah ke bawah. Sebutan ini berdasarkan pada fakta bahwa kontribusi UMKM terhadap Produk Domestik Regional Bruto (PDRB) dan penciptaan lapangan kerja, inovasi, dan ekonomi kreatif skala mikro kecil dan menengah.

Namun dengan kemajuan globalisasi ekonomi dunia membuat pelaku UMKM dihadapkan pada kemampuan untuk berdaya saing dengan perusahaan-perusahaan besar (korporasi) untuk meningkatkan jumlah output dan kualitas produk yang kompetitif. Secara nasional saat ini UMKM memang telah mengalami banyak kemajuan dan perkembangan besar bahkan sudah mampu naik kelas dan menjadi pemain dunia baik sebagai ekportir maupun importir. Dalam mencapai itu maka aspek yang paling penting dalam pengelolaan UMKM adalah bagaimana meningkatkan kapitasi usaha dengan menggejot investasi. Akan tetapi kondisi hari ini apalagi ditengah pandemic Covid-19 yang membuat UMKM semakin terpuruk justru tidak mampu menarik modal investasi dari penyedia dana ataupun investor. Padahal pemerintah juga telah meluncurkan kredit program yaitu Kredit Usaha Rakyat (KUR) dengan bunga lunak (bunga rendah) melalui bank-bank penyalur. Sejatinya UMKM tidak mengalami hambatan besar dalam mengakses KUR untu mendapatkan investasi namun faktanya jumlah kredit investasi yang tersalurkan ke sektor UMKM relatif rendah. Berikut data serapan kredit UMKM selama 5 tahun terakhir di Provinsi Aceh:

Table 2. Jumlah UMKM di Provinsi Aceh

\begin{tabular}{|c|c|c|}
\hline No & Tahun & Dalam triliun rupiah \\
\hline 1 & 2016 & 4,72 \\
\hline 2 & 2017 & 5,05 \\
\hline 3 & 2018 & 5,18 \\
\hline 4 & 2019 & 11,62 \\
\hline 5 & 2020 & 11,09 \\
\hline
\end{tabular}

Sumber: Bank Indonesia Provinsi Aceh

Dari tabel $1 \mathrm{di}$ atas dapat terlihat bahwa serapan kredit UMKM mengalami kenaikan sepanjang 5 tahun terakhir. Namun bila dilihat sesuai skemanya kredit investasi rata-rata hanya $10 \%$ dari total kredit bahkan per Juni 2021 pertumbuhan kredit investasi di Aceh mengalami penurunan -36,90 persen (Bank Indonesia).

Karena dampak investasi terhadap UMKM sangat besar pengaruhnya. Maka penting permasalahan ini untuk dikaji sebab apa yang membuat kucuran kredit investasi UMKM rendah, dan analisis keputusan investasi yang salah akan menyebabkan usaha menimbulkan masalah bahkan mengalami kebangkrutan.

Oleh karena itu sangat penting melakukan analisis keputusan investasi sehingga kredit investasi yang tersedia di lembaga keuangan bank dapat diserap secara optimal. Di sisi lain berbagai macam program pelatihan dan pemberdayaan UMKM dilakukan oleh pemerintah dan berbagai macam stakeholder lainnya terus dilakukan. Namun seakan UMKM 
masih saja sangat sulit berkembang dan berakselerasi lebih cepat untuk mandiri. Termasuk pula adanya dukungan perbankan dalam memenuhi kebutuhan modal investasi untuk melakukan ekspansi usaha.

Tabel 1. Kredit Investasi UMKM Aceh

\begin{tabular}{|c|c|c|}
\hline No & Tahun & Jumlah Kredit \\
\hline 1 & 2016 & 64.543 \\
\hline 2 & 2017 & 65.214 \\
\hline 3 & 2018 & 68.310 \\
\hline 4 & 2019 & 70.638 \\
\hline 5 & 2020 & 74.810 \\
\hline
\end{tabular}

Sumber: Bank Indonesia Provinsi Aceh

Analisis serapan kredit investasi yang bersumber dari dana perbankan oleh UMKM di Aceh masih tergolong sangat rendah bila dibandingkan dengan UMKM diluar Aceh terutama UMKM di pulau Jawa. Menurut survey Bank Indonesia Provinsi Aceh (2019) salah satu kendala yang dihadapi oleh pihak bank dalam memberikan kredit usaha bagi UMKM adalah tidak tersedianya laporan keuangan yang sebagai alat analisis kelayakan usaha oleh analis kredit di bank. Namun secara kasat mata kinerja UMKM terlihat sangat bagus. Hal ini ditandai dengan kemampuan keuangan yang relatif lebih stabil sehingga kewajiban-kewajiban jangka pendeknya dapat dilakukan oleh UMKM. Penelitian ini mencoba untuk menganalisis hubungan kinerja keuangan UMKM dengan serapan kredit investasi terutama Kredit Usaha Rakyat (KUR) yang menyebabkan rendahnya serapan kredit investasi oleh UMKM di Aceh, juga hubungan kinerja keuangan UMKM dengan serapan kredit investasi UMKM di Aceh, kemudian bagaimana arah hubungan kinerja keuangan UMKM dan serapan kredit investasi UMKM di Aceh.

\section{Literature Review}

Perkembangan kredit UMKM di Provinsi Aceh dalam satu dekade terakhir mengalami peningkatan seiring dengan membaiknya situasi keamanan daerah dan situasi politik lokal yang juga cenderung kondusif. Isu partai lokal yang relatif positif mendukung Pemerintah Aceh telah ikut memberikan insentif bagi pertumbuhan ekonomi daerah. Hal ini dapat dilihat pada peningkatan PDRB dengan tren naik. Situasi tersebut mendorong masyarakat untuk mengambil kesempatan membangun usaha UMKM. Keberadaan UMKM dan lembaga keuangan merupakan dua pilar perekonomian yang saling terkait untuk menciptakan pertumbuhan. UMKM di satu sisi membutuhkan permodalan dari perbankan, sementara perbankan di sisi lain membutuhkan pasar kredit dari modal yang mereka kelola. Maka hubungan ini secara teori disebutkan memiliki kausalitas.

Menurut Case dan Fair (2007), dalam Apriana (2016), pertumbuhan ekonomi ditandai dengan peningkatan output dalam suatu perekonomian. Pertumbuhan ekonomi daerah biasanya diindikasikan dengan meningkatnya produksi barang dan jasa yang diukur melalui PDRB (Apriana, 2016). Selain itu, Mankiw (2003), mengatakan capital atau modal merupakan sumber utama dalam menciptakan pertiumbuahan ekonomi.

Dengan semakin meningkatnya jumlah pelaku usaha atau unit usaha produktif baik usaha perseorangan maupun badan usaha menciptakan kesempatan bagi lembaga keuangan terutama perbankan untuk terserapnya kredit. Dengan jumlah UMKM di Aceh sebanyak 74.810 unit merupakan pangsa pasar yang relatif besar bagi kredit/pembiayaan bank. Penyaluran kredit memiliki peranan penting dalam perekonomian terutama untuk mengejar pertumbuhan (growth). Peranan kredit dalam mendorong pertumbuhan ekonomi dapat berarti adanya penciptaan lapangan kerja melalui perluasan usaha, peningkatan produksi, dan munculnya unit-unit usaha baru.

Menurut Hamdani et al (2018), pengertian kredit secara etimologis secara istilah kredit berasal dari bahasa, pengertian kredit secara etimologis secara istilah kredit berasal dari bahasa Yunani (credere) yang berarti kepercayaan (truth/faith) yaitu apabila suatu pihak memperoleh kredit dari pihak lain berarti ianya memperoleh kepercayaan. Artinya pihak pemberi kredit memberikan kepercayaan kepada pihak tersebut bahwa sejumlah uang atau barang yang dipinjamkan dapat dikembalikan. 


\section{Usaha Mikro Kecil dan Menengah}

Menurut Uundang-undang Nomor 20 Tahun 2008 tentang UMKM adalah usaha produktif yang berdiri sendiri yang dilakukan oleh orang perorangan atau badan usaha yang bukan merupakan anak perusahaan atau bukan cabang perusahaan yang dimiliki, dikuasai, atau menjadi bagian baik langsung maupun tidak langsung dari usaha menengah atau usaha besar yang memenuhi kriteria sebagai berikut: Usaha Mikro adalah sebagai berikut:

a) Memiliki kekayaan bersih lebih dari Rp50.000.000,- tidak termasuk tanah dan bangunan tempat usaha.

b) Memiliki hasil penjualan tahunan lebih dari Rp300.000.000,

Usaha Kecil adalah sebagai berikut:

a) Memiliki kekayaan paling banyak Rp50.000.000,- sampai dengan paling banyak Rp500.000.000,- tidak termasuk tanah dan bangunan tempat usaha atau

b) Memiliki hasil penjualan tahunan paling banyak Rp2.500.000.000,

Usaha Menengah adalah sebagai berikut:

a) Memiliki kekayaan paling banyak Rp50.000.000,- sampai dengan paling banyak Rp10.000.000.000,- tidak termasuk tanah dan bangunan tempat usaha atau

b) Memiliki hasil penjualan tahunan paling banyak Rp2.500.000.000,-sampai Rp50.000.000.000,

\section{Kredit Investasi}

Kredit investasi merupakan suatu kebijaksanaan kredit yang bersifat jangka menengah atau jangka panjang yang diberikan kepada pengusaha perorangan atau perusahaan dengan persyaratan dan prosedur khusus atau dengan pertimbangan kelayakan. Kredit investasi pada umumnya dipergunakan untuk membiayai kepentingan barang modal (Hamdani et al., 2020). Kredit investasi dapat dikatakan sebagai kredit yang digunakan untuk membeli atau pengadaan barang modal jangka panjang untuk kegiatan usaha nasabah.

\section{Kredit Usaha Rakyat (KUR)}

Kredit usaha rakyat adalah kredit atau pembiayaan kepada usaha mikro kecil dan menengah dalam bentuk pemberian modal kerja dan investasi yang didukung oleh fasilitas penjaminan untuk usaha produktif dan layak (feasible) namun mempunyai keterbatasan dalam pemenuhan persyaratan yang ditetapkan oleh perbankan. (Pratama, 2019).

Adapun menurut Wardana (2017), unsur-unsur yang terkandung dalam pemerian kredit meliputi: (1) kepercayaan, dimana analisis yang dilakukan terhadap permohonan/proposal kredit yang akan diberikan dapat dikembalikan sesuai dengan kesepakatan bersama; (2) agunan, setiap kredit/pembiayaan yang diberikan selalu disertai dengan jaminan tambahan atau agunan; (3) jangka waktu, pengembalian kredit berdasarkan pada jangka waktu tertentu yang layak. Setelah jangka waktu jatuh tempo maka kredit harus dilunasi sesuai yang disepakati; (4) risiko, jangka waktu pengembalian kredit tentu mengandung risiko, atau macetnya pelunasan kredit, risiko ini menjadi beban bank; (5) bunga bank, setiap pemberian kredit pasti selalu disertai dengan bunga atau margin yang harus dibayarkan oleh debitur kepada bank dengan besaran tertentu, dan ini merupakan keuntungan bagi bank; (6) kesepakatan bersama, semua persyaratan pemberian kredit atau prosedur pengembalian serta tata cara pengembaliannya atau akibat hukum yang ditimbulkan adalah hasil kesepakatan yang dituangkan dalam akta perjanjian kerja sama (kontrak) atau sering disebut Surat Perjanjian Kredit (SPK).

\section{Kinerja Keuangan}

Kinerja keuangan adalah tingkat pencapaian atau prestasi dari perusahaan dalam periode waktu tertentu dengan tujuan agar perusahaan tetap berdiri atau eksis (survive), untuk memperoleh laba (benefit) dan perusahaan dapat berkembang (growth). Tujuan tersebut dapat tercapai apabila perusahaan tersebut mempunyai performa yang baik. Kinerja perusahaan dapat dilihat dari tingkat penjualan, tingkat keuntungan, pengembalian modal, tingkat turn over dan pangsa pasar yang diraihnya. (Ismanto, 2016). 


\section{Metodologi Penelitian}

Penelitian ini menggunakan metode kuantitatif dengan jenis data sekunder time series 20192020. Analisis yang digunakan adalah analisis hubungan (kausalitas) yang merupakan salah satu analisis yang dikembangkan oleh Engle dan Granger (1987), untuk melakukan rekonsialisasi perilaku variabel ekonomi dalam jangka dan jangka panjang dengan bantuan software Eviews versi 7. Ruang lingkup penelitian ini dilakukan di Provinsi Aceh. Variabel yang akan digunakan ada tiga yaitu; Kredit Investasi (KI), Kinerja Keuangan (KK), dan jumlah UMKM. Berdasarkan analisis kausalitas, maka semua variabel diperlakukan secara simetris dimana seluruh variabel diperlakukan sebagai variabel endogen (Lailiyana, 2010). Sumber data dan jenis data yang digunakan adalah data yang diperoleh dari Bank Indonesia, Otoritas Jasa Keuangan (OJK), Dinas Koperasi dan UKM dan laporan keuangan UMKM. Pengumpulan data dilakukan melalui dokumen-dokumen, laporan, dan informasi yang tersedia pada lembaga tersebut. Selain itu data primer sebagai data pendukung dikumpulkan dengan melakukan wawancara langsung dan observasi lapangan.

\section{Hasil dan Pembahasan}

Sebelum uji kausalitas dilakukan perlu terlebih dahulu dilakukan uji stasioneritas data (unit root test). Data time sries memiliki masalah autokorelasi yang menyebabkan data tidak stasioner. Uji ini pada umumnya digunakan dengan menjalankan fungsi Augmented Dickey Fuller (ADF) dan Philips Perron (PP).

Table 3. Hasil Uji Akar Unit

\begin{tabular}{|c|c|c|c|c|}
\hline \multirow{2}{*}{ Variabel } & \multicolumn{2}{|c|}{ Level } & \multicolumn{2}{c|}{ First Difference } \\
\cline { 2 - 5 } & ADF & PP & ADF & PP \\
\hline LKI &,- 3157 &,- 1121 & $-10,89926^{* * *}$ & $-11,0062^{* * *}$ \\
& {$[0,617]$} & {$[0,705]$} & {$[0,0000]$} & {$[0,0000]$} \\
\hline LKK & $-2,6177$ & $-2,9305$ & $-4,1126^{* * *}$ & $-7,1754$ \\
& {$[0,267]$} & {$[0,156]$} & {$[0,0000]$} & {$[0,0000]$} \\
\hline
\end{tabular}

Keterangan: ${ }^{* * *}$ menunjukkan signifikansi pada tingkat $1 \%$

Hasil uji yang dilakukan semua variable tidak stasioner pada level I(0) baik ADF maupun PP. Namun stasioner pada deferensi orde pertama I(I) dengan signifikansi pada 1 persen seperti ditunjukkan pada table 3 diatas. Selanjutnya penentuan lag optimal dari variabel endogen sebagai varibel independen yang digunakan dalam model.

Tabel 4. Lag Optimal

\begin{tabular}{ccccccc}
\hline Lag & LogL & LR & FPE & AIC & SC & HQ \\
\hline 0 & -1445.585 & NA & $4.34 \mathrm{e}+11$ & 38.14696 & 38.26963 & 38.19599 \\
1 & -1146.553 & 558.7167 & $2.53 \mathrm{e}+08$ & 30.69877 & $31.31222^{*}$ & $30.94389 *$ \\
2 & -1132.333 & 25.07145 & $2.66 \mathrm{e}+08$ & 30.74562 & 31.84965 & 31.18684 \\
3 & -1121.187 & 18.47955 & $3.05 \mathrm{e}+08$ & 30.87334 & 32.46806 & 31.51067 \\
4 & -1098.706 & 34.90557 & $2.62 \mathrm{e}+08$ & 30.70278 & 32.78817 & 31.53620 \\
5 & -1078.995 & $28.52872^{*}$ & $2.44 \mathrm{e}+07^{*}$ & $30.60511^{*}$ & 33.18120 & 31.63465 \\
\hline
\end{tabular}

Keterangan: * menunjukkan lag terkecil

Tabel 5. Uji Kausalitas

Dalam penelitian ini menggunakan lag optimal berdasarkan hasil metode AIC yaitu lag 5 . Harris (1995:65) dalam Hamdani at al, (2019), menjelaskan bahwa jika lag yang digunakan terlalu sedikit, residual dari regresi tidak akan menampilkan white noise. Namun jika memasukkan terlalu banyak maka mengurangi kemampuan menolak (H0). Dari hasil uji pada table 4 di atas nilai terkecil yaitu metode AIC sebesar 30,60511 pada lag 5 .

\begin{tabular}{lccc}
\hline Null Hypothesis: & Obs & F-Statistic & Prob. \\
\hline LKI does not Granger Cause LKK & 24 & $2.02861 *$ & 0.0656 \\
LKK does not Granger Cause LKI & & 0.86571 & 0.5155 \\
\hline Keterangan: * signifikansi pada 10 persen & & &
\end{tabular}

Hasil pengujian kausalitas seperti ditunjukkan pada table di atas bahwa variabel LKI memiliki hubungan kausalitas satu arah dengan variabel LKK dengan probabiltas 0,065 dengan tingkat signifikansi 10 persen. Secara statistic variabel LKI memiliki kausalitas signifikan dengan variabel LKK. Ini berarti bahwa variabel Kredit Investasi memperngaruhi secara signifikan tingkat kinerja keuangan UMKM. Artinya hipotesis nol tidak dapat ditolak 


\section{Kesimpulan}

Berdasarkan uraian hasil penelitian dapat disimpulkan bahwa terdapat hubungan kausalitas satu arah antara variabel Kredit Investasi (LKI) dengan variabel Kinerja Keuangan (LKK) UMKM. Artinya kredit investasi yang dikucurkan oleh bank kepada UMKM dapat mempengaruhi kinerja keuangan UMKM dan hubungan tersebut positif dan signifikan pada taraf 10 persen. Hasil penelitian menunjukkan bahwa penyaluran kredit investasi oleh bank terhadap UMKM di Aceh dapat berdampak positif bagi pertumbuhan keuangan usaha UMKM.

\section{Daftar Pustaka}

Apriana, R. (2016). Analisis Kausalitas antara Penyaluran Kredit dengan Pertumbuhan Ekonomi (Studi Kasus pada BPD Provinsi Nusa Tenggara Barat). Jurnal Ilmiah Mahasiswa FEB, 4(2).

Case, K. E., \& Fair, R. C. (2007). Principles of microeconomics. Pearson Education.

Destiana, R. (2016). Analisis Faktor-Faktor Internal Yang Mempengaruhi Pembiayaan Usaha Mikro Kecil Dan Menengah (UMKM) Pada Bank Syariah Di Indonesia. Jurnal Riset Keuangan dan Akuntansi, 2(1).

Engle, R. F., \& Granger, C. W. (1987). Cointegration and error correction: representation, estimation, and testing. Econometrica: journal of the Econometric Society, 251-276.

Hamdani, H., Ismail, I., \& Murhadi, T. (2020). Analisis Kredit UMKM di Provinsi Aceh: Analisis Empiris Vector Error Correction Model (VECM). Jurnal EMT KITA, 4(2), 59-70.
Hamdani, H., Wahyuni, N., Amin, A., \& Sulfitra, S. (2018). Analisis Faktor-Faktor yang mempengaruhi Kinerja Keuangan Bank Umum Syariah yang terdaftar di Bursa Efek Indonesia (BEI)(Periode 2014-2016). Jurnal EMT KITA, 2(2), 6273.

Ismanto, H. (2016). Analisis kinerja keuangan UMKM tenun ikat troso jepara. Jurnal Economia, 12(2), 159-166.

Majid, M. S. A., \& Nasir, M. (2018). SMEs' Credit Demand And Economic Growth In Indonesia. Regional Science Inquiry, 10(2), 121-133.

Mankiw, N. G. (2003). Macroeconomics (Vol. 41). New York: Worth Publishers.

Muchammad, F. (2012). Faktor-faktor yang mempengarubi keputusan dalam pemberian keredit investasi oleh pt. Bpr surya artha utama surabaya (Doctoral dissertation, Faculty of Economics).

Pratama, D. (2019). Prosedur Pelaksanaan Kredit Usaha Rakyat (KUR) Pada PT. Bank Nagari Cabang Padang.

Wardana, A. S. A. A. (2017). Analisis faktorfaktor yang mempengaruhi minimnya permintaan kredit investasi pada pt. Bank sulselbar cabang bantaeng. Jurnal Ekonomi Balance Fakultas Ekonomi Dan Bisnis, 13(2).

Yuliana, A. H., \& Syechalad, M. N. (2015). Analisis Faktor-Faktor Yang Mempengaruhi Permintaan Kredit Usaha Mikro Kecil Dan Menengah Pada Bank Umum Di Kota Banda Aceh. Jurnal Ilmu Ekonomi: Program Pascasarjana Unsyiah, 3(1).context of automobile purchases. Journal of Product \& Brand Management, 16(1), 49-58. 